\title{
Asocierea dintre colita ulcerativă şi infecția cu Clostridium difficile la vârsta pediatrică - prezentare de caz
}

\author{
Alina Negrea', Lorena Elena Meliț1,2, Ana-Maria Şimon'1, Valentina Negrea ${ }^{3}$, \\ Cristina Oana Mărginean ${ }^{1,2}$ \\ ${ }^{1}$ Clinica Pediatrie I, Spitalul Clinic Judeţean de Urgenţă, Tg. Mureş, România \\ ${ }^{2}$ Universitatea de Medicină, Farmacie, Ştiinţe şi Tehnologie \\ "G.E. Palade", Tg. Mureş, România \\ ${ }^{3}$ Clinica Boli Infecţioase I, Spitalul Clinic Judeţean Mureş, Tg. Mureş, România
}

\begin{abstract}
REZUMAT
Introducere. Colita ulcerativă (CU) este o patologie mai severă la copil decât la adult, cu o incidenţă în creştere la vârste mici. Exacerbările cele mai frecvente sunt datorate infecţiei cu Clostridium difficile (CD) şi pot duce la complicaţii severe.

Prezentarea cazului. Prezentăm cazul unui pacient în vârstă de 6 ani, diagnosticat cu colită ulcerativă la vârsta de 5 ani, internat în clinica noastră pentru scaune diareice apoase cu sânge, dureri abdominale, inapetenţă, scădere ponderală. Examinările paraclinice la internare au evidenţiat anemie, leucocitoză cu neutrofilie, tulburări hidro-electrolitice, hipoalbuminemie severă. Testul de deteç̧ie a toxinelor A şi B pentru CD din materiile fecale a fost pozitiv, coprocultura negativă. Datele anamnestice, clinice şi paraclinice au stabilit diagnosticul de infecţie cu CD asociată cu exacerbarea CU. Iniţial, evoluţia sub puls-terapie cu Solu-Medrol şi antibioterapie cu Metronidazol iv a fost uşor favorabilă, însă cu perioadă de declin la 5 zile după trecerea per os a corticoterapiei. Astfel încât a fost nevoie de reluarea corticoterapiei iv şi asocierea Vancomicinei. Sub tratamentul instituit, simptomatologia s-a ameliorat, cu normalizarea parametrilor paraclinici, iar după 21 de zile de internare pacientul a fost externat.

Concluzii. Coexistenţa infecţiei cu CD la pacienţii pediatrici cu CU rămâne o adevărată provocoare, din cauza ratei mari de recurenţă şi a mortalităţii mai crescute faţă de populaţia generală. Evoluţia ondulantă sub tratament, dar şi profilul psihologic al pacientului au particularizat cazul.
\end{abstract}

Cuvinte cheie: colită ulcerativă, exacerbare, Clostridium difficile, antibioterapie

\author{
Abrevieri \\ BII - boală inflamatorie intestinală $\quad \mathrm{PCR}$ - proteina C-reactivă \\ CU - colită ulcerativă $\quad \mathrm{Hg}-$ hemoglobină \\ $\mathrm{BC}$ - boală Crohn Htc - hematocrit \\ $\mathrm{CD}$-Clostridium difficile $\quad$ VSH - viteza de sedimentare a hematiilor
}

\section{INTRODUCERE}

Colita ulcerativă (CU) şi boala Crohn (BC) fac parte dintr-un grup heterogen de inflamaţii cronice ale tractului gastro-intestinal, idiopatice, nespecifice, reunite sub denumirea de boli inflamatorii intestinale (BII). Termenul de boală inflamatorie intestinală ne- clasificată se utilizează în situaţile în care nu se pot diferenţia CU şi BC, conform criteriilor ESPGHAN (1). Etiopatogenia acestei patologii este plurifactorială, implicând factori de mediu, imunologici, genetici, dar şi factori ce ţin de microbiota intestinală (2). Interacţiunea dintre aceşti factori este extrem de importantă în debutul bolii. $\mathrm{Cu}$ toate că stresul, anxietatea 
pot favoriza puseele de CU, nu pot fi clar implicate în apariţia bolii, însă contribuie într-o măsură destul de importantă la evoluţia acestei patologii (3). CU afectează doar colonul şi rectul. În funcţie de extinderea leziunilor, diagnosticul topografic, conform clasificării Paris, poate fi de: rectită - E1, este afectat doar rectul; colită stângă - E2 distal de flexura splenică; colită extinsă - E3 până la flexura hepatică sau în amonte de aceasta - E4 (4). Inflamaţia este continuă şi limitată la mucoasă. Cu toate acestea, colita extinsă reprezintă cea mai frecventă formă de colită ulcerativă la copil, spre deosebire de adult $(1,4)$. Un sfert dintre cazurile de boală inflamatorie intestinală sunt diagnosticate la copiii sub vârsta de 18 ani (5), vârsta medie de debut fiind între 10 şi 12 ani, cu tendinţă la scădere în ultimii ani. Incidenţa CU cu debut pediatric este în creştere, fiind foarte diferită pe tot globul. Ţările industrializate din Europa de Vest, Scandinavia, America de Nord se află pe primele locuri ca incidenţă, cu un caz la 250 de persoane sănătoase (6). CU are o prevalenţă între 0,2 şi 6,7 la 1.000 de copii $(5,6)$. CU se caracterizează predominant prin manifestări digestive, precum dureri abdominale, scaune diareice cu sau fără elemente patologice, tenesme, hematochezie, greţuri, vărsături, scădere ponderală (7), însă pot fi prezente şi manifestări extraintestinale: artrită, leziuni cutanate, afectare hepatică sau leziuni oculare (8). Abordarea terapeutică a pacienţilor pediatrici cu CU este complexă şi trebuie să fie individualizată în funcţie de particularităţile pacientului, forma de boală, dar şi de prezenţa sau absenţa unor posibile complicaţii. Scopurile terapiei sunt obţinerea şi menţinerea remisiunii, evitarea complicaţiilor, dar şi asigurarea unei calităţi a vieţii corespunzătoare vârstei pacientului (1). Evoluţia CU constă într-o succesiune de pusee şi perioade de acalmie. Conform ultimelor date din literatură, $20 \%$ dintre exacerbări sunt date de către infecţia cu Clostridium difficile (CD), morbiditatea în aceste context fiind semnificativă (9).

CD este un bacil Gram pozitiv, anaerob, a cărui virulenţă se datorează eliberării toxinelor A şi B în intestin. Se cunoaşte faptul că mai multe categorii de pacienţi au risc crescut de infecţie, printre care se numără pacienţii trataţi cu antibiotice cu spectru larg pe o perioadă lungă de timp, cei polispitalizaţi, imunocompromişi, care se află pe tratament cu inhibitori de pompă protonică sau antagonişti de receptori H2 (10). Incidenţa infecţiei cu CD la pacienţii pediatrici cu BII nu este clară, sugerându-se că $24,7 \%$ dintre cazurile de CU la copii se pot asocia cu această infecţie comparativ cu 9\% la copiii fără BII (11). Simptomele frecvente ale formelor uşoare şi moderate constau în diaree apoasă, febră şi dureri abdominale uşoare (12). Metronidazolul reprezintă prima linie de tratament în cazul primului episod al infecţei, cu forme uşoare, în timp ce Vancomicina per oral (po) se recomandă pentru cele moderate şi severe. Asocierea dintre Vancomicină po şi Metronidazol intravenos (iv) se recomandă în cazurile severe sau cu complicaţii sistemice $(13,14)$.

Scopul acestei prezentări este de a sublinia provocările apărute în diagnosticul şi managementul unui pacient cu colită ulcerativă şi exacerbarea acesteia în contextul unei infecții cu CD.

\section{PREZENTAREA CAZULUI}

\section{Motivele internării}

Prezentăm cazul unui preşcolar în vârstă de 6 ani, de sex masculin, diagnosticat în urmă cu 7 luni cu $\mathrm{CU}$, pentru care a necesitat multiple internări, dar fără tratament adecvat la domiciliu din cauza lipsei de complianţă a părinţilor. Simptomatologia actuală a debutat cu aproximativ două săptămâni anterior internării, cu dureri abdominale, scaune diareice apoase cu sânge, febră, inapetenţă, scădere ponderală.

\section{Examen obiectiv}

La internare, examenul obiectiv decelează pacient hipostenic, cu stare generală influenţată, facies suferind, tegumente palide, turgor cutanat diminuat, edeme la nivelul membrelor inferioare bilateral, cu semnul godeului pozitiv, limbă saburală, echilibrat cardio-respirator, abdomen destins, dureros la palparea superficială şi profundă, tranzit intestinal accelerat.

\section{Criterii de diagnostic}

Investigaţiile iniţiale au evidenţiat anemie (Hg: 9,5 g/dl; Htc: 27,9\%), leucocitoză: 24.670/mm³, neutrofilie $73,9 \%$, proteina C-reactivă crescută (PCR: 148,62 mg/l), hiponatremie şi hipopotasemie (sodiu: $128 \mathrm{mmol} / 1$, potasiu: 2,81 $\mathrm{mmol} / \mathrm{l}$ ), hipoalbuminemie (albumină: 1,7 g/dl), hipoproteinemie $(4,35 \mathrm{~g} / \mathrm{dl})$. Ca urmare a tabloului clinic, se recoltează probe din scaun pentru detecţia toxinelor CD A şi B, $\mathrm{cu}$ rezultat pozitiv pentru ambele exotoxine, coprocultura fiind negativă. Astfel, s-a stabilit diagnosticul de infecţie cu C. difficile asociată cu exacerbarea CU. 


\section{Tratament}

Având în vedere evoluţia trenantă, s-a iniţiat pulsterapie cu Solu-Medrol, Metronidazol iv timp de 7 zile, din cauza toleranţei digestive scăzute, ulterior per os până la 14 zile, simptomatice (Smecta, Hidrasec, Enterol), albumină umană. Evoluţia clinică şi paraclinică pe perioada corticoterapiei iv, respectiv a antibioterapiei iv a fost uşor favorabilă, cu ameliorarea simptomatologiei. După 5 zile de la trecerea la corticoterapie po, au reapărut scaunele diareice cu sânge, cu markeri inflamatori în creştere, leucocitoză cu neutrofilie, motiv pentru care se reintroduce corticoterapia iv, tratament cu Vancomicină po şi imunomodulator cu Azatioprină. Sub tratamentul instituit, evoluţia a fost lent favorabilă, motiv pentru care pacientul a fost externat după 21 de zile cu corticoterapie po. Ţinând cont de faptul că pacientul a prezentat tulburări anxioase, iritabilitate, dureri abdominale uneori de tip funcţional, somatizare, necomplianţă la regimul alimentar, s-a solicitat consult de neuropsihiatrie pediatrică, stabilindu-se diagnosticul de sindrom psihoorganic cu elemente anxioase şi anxietate de separare.

\section{Monitorizare și prognostic}

Complianţa scăzută a familiei şi reşedinţa familiei într-o altă ţară au dus la imposibilitatea urmării evoluţiei acestui caz din cauza neprezentării la controalele periodice recomandate. Mai mult, complianţa redusă ar putea reprezenta o mare povară în ceea ce priveşte prognosticul acestui caz.

\section{DISCUȚII}

Studii epidemiologice recente sugerează o creştere a incidenţei bolilor inflamatorii intestinale la vârste mici $(15,16)$. În funcţie de vârsta la debut, BII poate fi clasificat cu debut pediatric la copiii sub 17 ani, debut precoce sub 10 ani, foarte precoce sub 6 ani, respectiv debut neonatal $(17,18)$, sugerându-se că debutul neonatal sau infantil au o evoluție clinică severă şi rată crescută de rezistenţă la terapia imunosupresoare $(19,20)$. Cazul pacientului nostru a avut un debut foarte precoce, la vârsta de 5 ani, spre deosebire de vârsta medie de debut raportată în literatură, între 10 şi 12 ani.

Exacerbarea acută severă a CU este o urgenţă medicală. Este binecunoscut faptul că rata mortalităţii se reduce considerabil sub puls-terapie cu corticoizi
(21). Conform organizaţiei European Crohn's and Colitis, diagnosticul de exacerbare a CU în cazul adulţilor presupune prezenţa a mai mult de 6 scaune apoase plus unul dintre următoarele criterii: tahicardie ( $\geq 90 \mathrm{bpm}$ ), temperatura: peste $37,8^{\circ} \mathrm{C}$, anemie (Hgb sub 10,5 g/dl) sau viteza de sedimentare a hematiilor (VSH) peste $30 \mathrm{~mm} / \mathrm{h}$ (22). La pacienţii pediatrici, scorul Pediatric Ulcerative Colitis Activity Index (PUCAI) stabileşte gradul de severitate al CU (23). Acest algoritm înglobează parametrii precum durerea abdominală, prezenţa sau absenţa sângerării rectale, consistenţa şi frecvenţa scaunelor, respectiv nivelul de activitate al pacientului. Astfel, un scor peste 65 este echivalent cu activitate severă. Mai mult, lipsa de răspuns la corticoterapie iv în ziua a 5-a de administrare este semn de CU steroid-refractară (23). Pacientul nostru a beneficiat de puls-terapie, cumulând un scor de 80 .

În ciuda faptului că face parte din flora intestinală a sugarilor, în timpul copilăriei, există o scădere dependentă a colonizării cu CD. Vârsta de 5 ani este considerată pragul de maturarea microbiomului, după care scade rata purtătorilor de CD (24). Ținând cont de perturbările microbiomului intestinal care sunt asociate BII, putem considera că aceşti pacienţi au un risc crescut pentru infecţia cu CD. Conform unui studiu, rata portajului asimptomatic de CD la pacienţii cu BII a fost mai mare la vârsta pediatrică comparativ cu cea adultă, respectiv $17 \%$ comparativ cu 8,2\% (25). În cazul pacientului nostru, nu putem spune cu certitudine că nu era un purtător asimptomatic şi că patogenitatea $C$. difficile s-a exprimat în contextul exacerbării. Astfel, este dificil de precizat dacă infecţia cu CD a fost triggerul pentru exacerbarea $\mathrm{CU}$ sau invers. Pacienţii cu ambele toxine pozitive pentru $C$. difficile pot avea simptome clinice mai grave, fapt ce s-a observat şi în cazul prezentat (26). Un studiu desfăşurat în Beijing pe 30 de pacienţi pediatrici cu BII a arătat că incidenţa ambelor toxine pozitive este mică şi doar un pacient a avut ambele toxine pozitive (26).

Infecţia cu CD la pacienţii cu BII are o rată mare de recurenţă şi morbiditate mai crescută faţă de populaţia generală, necesitând spitalizare îndelungată şi escaladarea terapiei (27). Cu toate acestea, pacienţii cu CU sau BC au o mai mare susceptibilitate la infecţie cu CD în comunitate, spre deosebire de ceilalţi pacienţi care dezvoltă infecţii nosocomiale cu CD (28). Perioadele de exacerbare a CU se asociază frecvent cu această infecţie, fiind dificil de diferenţiat 
cele două entităţi, al căror tablou clinic este similiar $(7,8,12)$. Majoritatea simptomelor menţionate anterior au fost prezente şi în cazul pacientului nostru, primul puseu al bolii survenind la aproximativ 7 luni de la stabilirea diagnosticului de BII. Într-un studiu pediatric recent efectuat, $\mathrm{Hg}$, trombocitele, VSH-ul şi albumina au avut valori normale în momentul diagnosticului în 54\% dintre cazurile de CU uşoară, situaţie care nu a fost întâlnită în cazul exacerbării (29). În mod similar, pacientul nostru a prezentat modificări majore ale parametrilor de laborator în contextul exacerbării, cu o evoluţie lent favorabilă sub tratament, însă care pot fi explicate şi de infecţia cu CD. Analizele de laborator în infecţia cu CD sunt nespecifice, în prim plan fiind leucocitoza $\left(20-50.000 /{ }^{3}\right)$, cu neutrofilie importantă (30). Diagnosticul etiologic este stabilit prin evidenţierea prezenţei toxinei CD în materiile fecale (15). În concordanţă, pacientul nostru a prezentat leucocitoză cu neutrofilie, iar diagnosticul a fost stabilit prin evidenţierea ambelor toxine în materiile fecale.

În vederea stabilirii unei conduite terapeutice optime şi evaluarea capacităţii de predicţie, precum şi facilitarea evaluării bolii, se remarcă utilitatea folosirii scorului ATLAS pentru colita cu CD, cuprinzând parametri precum vârsta, temperatura, numărul de leucocite, albumina şi folosirea unui antibiotic sistemic simultan (31). Un studiu care a a evaluat gradul de severitate al infecţiei cu CD cu ajutorul acestui scor a demonstrat că pacienţii cu un scor $\leq 3$ au avut un prognostic excelent, cei cu un scor între 3 şi 7 au avut probabilitate mare de colectomie, iar scorul peste $8 \mathrm{~s}$-a asociat cu mortalitate de $100 \%$ (32). Conform datelor, pacientul nostru a acumulat un scor de $2 . \mathrm{Cu}$ toate acestea, nu am găsit studii în literatură care să evidenţieze aplicabilitatea şi în rândul pacienţilor pediatrici. Metronidazolul este considerat prima opţiune de tratament în cazul copiilor cu BII şi enterocolită acută cu CD (33), fără a exista studii care să evidenţieze necesitatea unei alte linii de antibioterapie. În cazul prezentat, am optat pentru administrarea acestuia intravenos datorită toleranței digestive scăzute timp de 7 zile, ulterior cu administrare po până la 14 zile. $\mathrm{Cu}$ toate că nu s-a observat rezistenţă la Metronidazol în tulpinile pediatrice de CD (34), evoluţia cazului nostru, respectiv încadrarea într-o formă severă, a necesitat asocierea de Vancomicină. Mai mult, tratamentul instituit a fost unul complex care a inclus antibioterapie, puls-terapie cu Solu-Medrol, administrare de albumină umană, tratament imunosupresor (Azatioprină) şi simptomatice.

\section{CONCLUZII}

Pacientul pediatric cu CU şi infecţie cu CD rămâne o adevărată provocare, din cauza creşterii alarmante a morbidităţii, mortalităţii şi a costurilor ridicate aferente asistenţei medicale. Complianţa aparţinătorilor în cazul pacienţilor pediatrici cu BII este esenţială în ceea ce priveşte prognosticul acestei patologii.

Conflict of interest: none declared Financial support: none declared

\section{BIBLIOGRAFIE}

1. Birimberg-Schwartz L, Zucker DM, Akriv A, et al. Pediatric IBD Porto group of ESPGHAN. Development and Validation of Diagnostic Criteria for IBD Subtypes Including IBD-unclassified in Children: a Multicentre Study From the Pediatric IBD Porto Group of ESPGHAN. J Crohns Colitis. 2017;11(9):1078-84.

2. Benchimol El, Fortinsky KJ, Gozdyra P et al. Epidemiology of pediatric inflammatory bowel disease: A systematic review of international trends. Inflammatory Bowel Diseases 2011; 17(1):423-439.

3. Abraham BP, Kahn SA, Transition of Care in Inflammatory Bowel Disease. Gastroenterol Hepatol (NY). 2014;10(10):633-640.

4. Levine A, Griffiths A, Markowitz J et al. Pediatric Modification of the Montreal Classification for Inflammatory Bowel Disease: The Paris Classification. Inflammatory Bowel Disease 2011;17(6):1314-1321.

5. Molodecky NA, Soons IS, Rabi DM et al. Increasing incidence and prevalence of the inflammatory bowel diseases with time, based on systematic review. Gastroenterology 2012;142(1):46-54

6. Siew C Ng, Hai Yun Shi, Hamidi N, et al. Worldwide incidence and prevalence of inflammatory bowel disease in the 21st century: a systematic review of population-based studies, The Lancet 2017; 390(10114):2769-2778

7. Kelsen J, Baldassano RN. Inflammatory bowel disease: The difference between children and adults. Inflammatory Bowel Diseases 2008;14(Suppl-2):S9-S11.

8. Jose FA, Garnett EA, Vittinghoff $E$ et al. Development of Extraintestinal Manifestations in Pediatric Patients with Inflammatory Bowel Disease. Inflammatory Bowel Diseases 2009;15(1):63-68.

9. Turner D, Simon T, Griffiths AM et al. Consensus for Managing Acute Severe Ulcerative Colitis in Children: A Systematic Review and Joint Statement From ECCO, ESPGHAN, and the Porto IBD Working Group of ESPGHAN. American Journal of Gastroenterology 2011:106(4)574-588.

10. Adams DJ, Eberly ME, Rajnik M et al. Risk Factors for CommunityAssociated Clostridium difficile Infection in Children. The Journal of Pediatrics 2017:186:105-109.

11. Hourigan SK, MD, Sears CL, Hemker MO. Clostridium difficile Infection in Pediatric Inflammatory Bowel Disease. Inflamm Bowel Disease. 2016;22(4):1020-1025.

12. Kassper D, Fauci A, Harrison's Infectious Disease, 3rd Edition, New York: McGraw-Hill Education Medical, 2017;294-298.

13. Bradley SJ et al. 2020 Nelson's Pediatric Antimicrobial Therapy, 26th Edition. American Academy of Pediatrics, 2020;105-107. 
14. Wultańska D, Banaszkiewicz A, Radzikowski A et al. Clostridium difficile infection in Polish pediatric outpatients with inflammatory bowel disease. European Journal of Clinical Microbiology \& Infectious Diseases 2010;29:1265-1270.

15. Heyman MB, Kirschner BS, Gold B et al. Children with early-onset inflammatory bowel disease (IBD): Analysis of a pediatric IBD consortium registry. The Journal of Pediatrics 2005;146(1):35-40.

16. Muise AM, Snapper SB, Kugathasan S et al. The age of gene is discovery in very early onset inflammatory bowel disease. Gastroenterology-AGA 2012;143(2):285-288.

17. Ouahed J, Spencer E, Kotlarz D et al. Very Early Onset Inflammatory Bowel Disease: A Clinical Approach With a Focus on the Role of Genetics and Underlying Immune Deficiencies. Inflammatory Bowel Diseases 2020;26(6):820-842.

18. Kelsen JR, Sullivan KE, Shervin R et al. North American Society for Pediatric Gastroenterology, Hepatology, and Nutrition Position Paper on the Evaluation and Management for Patients With Very Early-onset Inflammatory Bowel Disease. J Pediatr Gastroenterol Nutr. 2020;70(3):389-403.

19. Seo JK. Pediatric inflammatory bowel disease (IBD): phenotypic, genetic and therapeutic differences between early-onset and adult-onset IBD. Korean J Ped Gastroenterol Nutr. 2011;14(1):1-25.

20. Cannioto Z, Berti I, Martelossi S et al. IBD and IBD mimicking enterocolitis in children younger than 2 years of age. European Journal of Pediatrics 2009;168:149-155.

21. Truelove SC, Witts LJ. Cortisone in ulcerative colitis; final report on a therapeutic trial. British Medical Journal 1955;2:1041-1048.

22. Travis SPL, Stange EF, Lémann M et al. European evidence-based consensus on the management of ulcerative colitis: current management. Journal of Crohn's and Colitis 2008;2(1):24-62.

23. Turner D, Otley AR, Mack D et al. Development, validation, and evaluation of a pediatric ulcerative colitis activity index: a prospective multicenter study. Gastroenterology 2007;133:423-432.

24. Kellermayer R. Burdening Questions About Clostridium difficile in Pediatric Inflammatory Bowel Diseases. Journal of Pediatric Gastroenterology and Nutrition 2015;60(4):421-422.
25. Mezoff E, Mann EA, Hart WK et al. Clostridium difficile Infection and Treatment in the Pediatric Inflammatory Bowel Disease Population. J Pediatr Gastroenterol Nutr. 2011;52(4):437-441.

26. Li D, Guo S, Guan DX, Zhao CN, Xu XW. [Infection rate and clinical characteristics of toxigenic Clostridium difficile in children with inflammatory bowel disease]. Zhonghua Er Ke Za Zhi. 2020 Jul 2;58(7):564-569.

27. Ananthakrishnan AN, McGinley EL, Binion DG. Excess hospitalisation burden associated with Clostridium difficile in patients with inflammatory bowel disease. Gut. 2008;57:205-210.

28. Issa M, Ananthakrishnan AN, Binion DG. Clostridium difficile and inflammatory bowel disease. Inflammatory Bowel Diseases 2008; 14(10):1432-1442.

29. Mack DR, Langton CR, Markowitz J et al. Laboratory Values for Children With Newly Diagnosed Inflammatory Bowel Disease. Pediatrics 2007;119(6):1113-9.

30. Cupsa A et al. Boli Infectioase transmisibile. Editura Medicală Universitară, Craiova, 2006;10.53-10.55.

31. Cophra T, Miller M, Severson R et al. ATLAS-A Bedside Scoring System Predicting Mortality Due to Clostridium difficile Infection (CDI) in Elderly Hospitalized Patients (abs). Infectious Disease Society of America, 2010.

32. Hernández-García R, Garza-González E, Miller M et al. Application of the ATLAS score for evaluating the severity of Clostridium difficile infection in teaching hospitals in Mexico. The Brazilian Journal of Infectious Diseases 2015;19(4):399-402.

33. Gawronska A, Banasiuk M, Lachowicz D et al, Metronidazole or Rifaximin for Treatment of Clostridium difficile in Pediatric Patients with Inflammatory Bowel Disease: A Randomized Clinical Trial. Inflamatory Bowel Disease 2017;23(12):2209-2214.

34. Wultańska D, Woszczatyński PO, Pituch $\mathrm{H}$ et al. Survey of susceptibility of clinical Clostridium difficile strains isolated from patients hospitalised in different departments of paediatric hospital to antimicrobial agents. Med Dosw Mikrobiol. 2007;59(2):161-8. 